\title{
Considering the Baptism of Edgardo Mortara in the Context of Catholic Teachings and Rituals Then and Now
}

\author{
PAUL TURNER \\ paultu1@me.com \\ Cathedral of the Immaculate Conception, Kansas City MO 64105
}

Catholics regard baptism as the doorway to salvation. Faithful parents proudly present their infant children for baptism as a testimony of their own belief and of their desire to share it with the next generation. Baptism is the fruit of evangelization, even within families. When the baptism of an infant does not take place, traditional Catholics fear not only the loss of family customs and rituals, but the ultimate salvation of the child, with whom they yearn to share life not only in this world, but in the next. Catholics feel concern then even for infants outside their religious family. To understand the actions that such concerns prompt and the desperation that they imply, it helps to take a broader view of the baptismal ritual, a celebration steeped in proud ceremony, but most of which may be discarded in the case of an emergency.

Edgardo Mortara's baptism by a maid in his parental home in 1852 was not typical, but it was licit. In order to understand this historical event and similar contemporary situations, this essay addresses the ritual and theology of baptism before and after the Second Vatican Council.

\section{Normal Catholic Baptism in the Nineteenth Century}

The Catholic baptism of a child in the mid-nineteenth century usually took place at a local parish church. The pastor typically conducted the ceremonies under the approving eyes of parents and godparents. He may have baptized several children of different parents in the same ceremony. Most of these babies would have been younger than one year because parents were expected to have their child baptized "as soon as possible." In practice, baptism took place so soon that

\footnotetext{
1 "De sacramento baptismi rite administrando" 39, The Roman Ritual in Latin and English with Rubrics and Plainchant Notation: The Sacraments and Processions, trans. and ed. Philip T. Weller,
} 
some mothers recovering from childbirth remained at home in bed. A mother's absence from the baptism strengthened the role of godparents, especially of the godmother, who tended the child throughout the ceremony. Infant baptism in the Catholic Church evolved partly from a high infant mortality rate generating a realistic fear that every newborn was in danger of death. Baptism promised eternal life for those who might not long survive earthly life. Yet, athwart this fear, a typical baptism awaited a Sunday when a priest could administer its full ceremonies. In rare circumstances when the death of the child seemed imminent, someone else administered the sacrament minimally and privately. Normally, though, a baptism was quite complex.

At the beginning of the ceremony, the priest stood at the door of the church, wearing a cassock, surplice and purple stole. He asked the infant, "What are you asking of the Church of God?" The incongruity of asking an infant this question gives pause until one realizes that the baptism of infants derived from more ancient ceremonies for the baptism of adults. The question resembles the question Peter asked Cornelius in the Acts of the Apostles 10:29, "May I ask, then, why have you summoned me?"2 The thirteenth-century Pontifical of the Roman Curia had the bishop pose this question to those wishing to enter the catechumenate, ${ }^{3}$ and it remained in the nineteenth-century Catholic baptismal ceremonies for adults and for children. Here and in other similar places the ritual instructed the godparent to respond on behalf of the child.

After this brief dialogue, the priest blew three puffs of air from his mouth onto the face of the infant. Having first addressed the child, the priest then commanded the unclean spirit within to yield to the Holy Spirit. With his thumb the priest traced the sign of the cross on the infant's forehead and breast, addressing the child once again. Finally the priest prayed to God for the infant's present and future protection.

Holding a small vessel of salt, the priest addressed the mineral, exorcizing it, and then he asked God to sanctify it. Addressing each infant by name, the priest placed "the salt of wisdom" on the child's tongue to enhance the prospects of eternal life. ${ }^{4}$

The priest offered more prayers and exorcisms, alternating his form of address between God and the unclean spirit. The priest then placed his hand on the child's head. He placed the left end of his stole over the child and led the infant into the church. There the priest prayed the Creed and the Lord's Prayer with the godparents. Before entering the baptistry, he addressed and exorcized the unclean spirit within the child. The priest licked his thumb and traced saliva on the mouth, ears and nose of the infant. He commanded that the child's ears and nostrils be

volume I (Boonville: Preserving Christian publications, Inc., 2007). Hereafter, Roman Ritual. All translations from Latin are mine.

${ }^{2}$ New American Bible, Revised Edition (used throughout). See Paul Turner, The Hallelujah Highway: A History of the Catechumenate (Chicago: Liturgy Training Publications, 2000), p. 160.

3 "Ordo ad cathecuminum faciendum" 1, Pontifical Romain au Moyen-Age: Le Pontifical de la curie Romaine au XIIIe siècle, ed. Michel Andrieu, Studi e Testi 87, p. 513.

4 "Ordo baptismi parvulorum" 7, Roman Ritual. 
opened. He asked the child to renounce Satan, and the godparent responded. He anointed the child with the oil of catechumens, speaking again directly to the infant. He wiped off excess oil with a cotton ball.

Just before entering the baptistry, the priest exchanged his purple stole for a white one. The godparents followed him to the font. The priest asked the child by name to profess faith in the Trinity, and the godparent responded.

In a climactic moment, the priest asked the child by name, "Do you wish to be baptized?"5 The godparent answered affirmatively. The priest poured baptismal water over the child's head in the form of a cross three times, once at each mention of the Persons of the Trinity, addressing the child by name while carefully reciting the formula, "I baptize you in the name of the Father, and of the Son, and of the Holy Spirit." Alternatively, the priest could baptize by triple immersion instead of pouring.

While the godparent held the child, the priest dipped his own thumb into chrism oil and traced the cross on the crown of the child's head while asking God to anoint the child with the chrism of salvation. The priest took a cloth and dried his thumb. He then placed a white linen cloth over the child's head and asked the child to carry it unstained to the judgment seat of Christ. He presented a lighted candle to the child or the godparent, while exhorting the infant to protect this baptism by keeping God's commands. The priest then dismissed the child: "Go in peace, and may the Lord be with you."

The ceremony for adult baptism was even more involved. In practice, many priests baptized adults with the rite of baptism for children because it was comparatively simpler. Noteworthy, though, is how the adult ceremony treated the baptism of a Jew. After the renunciation of Satan and the profession of faith in the Trinity, having traced the sign of the cross on the forehead and breast of the catechumen, the priest issued this command to a Jew: "Turn away from Jewish faithlessness. Renounce the Hebrew superstition."7 The candidate made no response; the priest simply pronounced this command.

\section{The Importance of Baptizing}

The significance of baptism can be traced to the teaching of Jesus Christ, who explained to Nicodemus, "no one can see the kingdom of God without being born from above.... No one can enter the kingdom of God without being born of water and the Spirit" (Jn 3:3, 5). At the end of his ministry, Jesus commanded his disciples, "Go, therefore, and make disciples of all nations, baptizing them in the name of the Father, and of the Son, and of the holy Spirit" (Mt 28:19). From the first Christian Pentecost when Peter began to preach repentance, forgiveness, and the gift of the Holy Spirit, "those who accepted his message were baptized." (Acts 2:41). Although the New Testament gives no concrete evidence for the bap-

\footnotetext{
5 “Ordo baptismi parvulorum" 18, Roman Ritual.

6 “Ordo baptismi parvulorum" 19, Roman Ritual.

7 “De baptismo adultorum” 10, Roman Ritual.
} 
tism of infants or children, it describes the baptisms of such great numbers that their inclusion may perhaps be inferred. Clear testimony of the baptism of infants arises from the earliest Christian centuries in writings such as those of Irenaeus and Origen, based on a combination of Jesus' openness to children and to the natural impulse of parents to share the necessities of life with their children. ${ }^{8}$

In time and until well into the twentieth century, church law and catechesis came to stress ever more strongly the absolute necessity of baptism. Baptism was called "the necessary means for obtaining eternal salvation." Even if one failed to receive it through no fault of one's own, "salvation is not obtained." In the case of unbaptized children, only martyrdom would ensure them eternal salvation. ${ }^{9}$

Because so much was at stake with baptism, the Church has permitted even those who were not ordained priests to administer the sacrament in exceptional circumstances. If Christ had said that baptism is necessary for salvation, and if Christ had commanded his followers to baptize all nations, and if someone was in danger of not receiving baptism, many Catholics sensed the imperative to baptize those who otherwise may not have received this "necessary means" for salvation.

In the case of emergency infant baptisms, the lengthy ceremonies were reduced to the bare essentials. ${ }^{10}$ The Roman Ritual in force between the Council of Trent and the Second Vatican Council teaches, "In danger of death, a non-solemn baptism may be administered by anyone having observed the proper matter, form and intention." 11 If the child survived, a priest supplied the rest of the ceremonies at the church as soon as possible. ${ }^{12}$ Anyone could administer baptism, even a nonbeliever, but the church recommended a specific hierarchy of preferred ministers: a priest, a deacon, a subdeacon, a cleric, a layperson, a man, and then a woman, unless for the sake of decorum a woman was preferred, or if among those present, a woman knew the baptismal formula and method better than any man there. ${ }^{13}$

In the nineteenth century, under normal circumstances, this is how baptisms took place. Under normal circumstances, a child was baptized at the request of parents. However, an additional exception pertained to the emergency baptism of non-Christian children: "An infant of unbelievers is licitly baptized even when parents are unwilling, whenever it is considered that the child's life is in danger, as long as it can be reasonably foreseen that the child will die before attaining the use of reason." 14

\footnotetext{
${ }^{8}$ Paul Turner, Ages of Initiation: The First Two Christian Millennia, (Collegeville: The Liturgical Press, 2000), CD-Rom Chapter Two, "Emerging Ritual Patterns."

9 Summa Theologiae moralis iuxta codicem iuris canonici, De Sacramentis, ed. H. Noldin and A. Schmitt (Innsbruck: Fel. Rauch, 1934), p. 56.

10 "De sacramento baptismi rite administrando," 28, Roman Ritual.

11 "De sacramento baptismi rite administrando," 16, Roman Ritual.

12 "De sacramento baptismi rite administrando," 28, Roman Ritual.

13 "De sacramento baptismi rite administrando," 28, Roman Ritual.

14 “De sacramento baptismi rite administrando," 24, Roman Ritual.
} 


\section{The Baptism of Edgardo Mortara}

In 1852 Anna Morisi, a Catholic teenager employed in the Jewish Mortara home in Bologna, performed an emergency baptism on one-year old Edgardo Mortara. ${ }^{15}$ She kept her action secret. In 1858 Vatican officials learned of the baptism and took the child from his home in Bologna to be raised a Catholic in Rome. ${ }^{16}$ An international sensation ensued. In order to contrast the 1852 ritual with a hypothetically similar situation today, this article focuses only on the baptism itself, not on the neuralgic issues concerning the taking of the child. Even so, testimony from various investigations of the Mortara baptism revealed so many inconsistencies that even the first sentence of this paragraph is controversial.

When did the event take place in 1852 ? Anna remembered it in the early wintry months of the new year, but Edgardo's doctor, Pasquale Saragoni, said that the child took ill in August. ${ }^{17}$

Was it an emergency? Anna believed that the child was dying, but Doctor Saragoni denied that the illness was that severe. ${ }^{18}$

How old was Anna at the time? She said that she was 14, but her baptismal certificate shows that she was $18 .^{19}$

How did the baptism take place? Anna had been hired to help tend the children in the Mortara household. When Edgardo fell ill, she feared that he was dying. Helpless to restore the handsome child to better health, she waited for his parents to leave the room, fetched a glass of well water, wet the fingers of her right hand, let several drops fall on the boy's head, and baptized him. ${ }^{20}$ However, Edgardo's father testified that Anna was never alone with the child. ${ }^{21}$ His mother said the same. ${ }^{22}$

Did Anna perform the baptism correctly? She says that she learned the method from Cesare Lipori, the local grocer. ${ }^{23}$ But he denied meeting her, teaching her how to baptize, or having anything to do with the baptism. ${ }^{24}$ Furthermore, without a witness, it was impossible to ascertain whether or not Anna used the correct words and poured water over Edgardo's head at the required time. ${ }^{25}$

\footnotetext{
${ }^{15}$ David I. Kertzer, The Kidnapping of Edgardo Mortara (New York: Alfred A. Knopf, 1997), pp. 4041, 47, 218.

${ }^{16}$ According to Anna, when a second child in the family fell ill, Anna's friend, an older servant named Regina Bussolari, suggested that Anna baptize that child. Anna refused, admitting to another person for the first time that she had already baptized Edgardo, and that he had survived. Bussolari denied having any knowledge of this conversation. The Vatican claimed to have learned of the baptism either from Regina or from Marianna Bajesi of Bologna, who testified that Regina shared the information with her (Kertzer, 207, 210-211, 148).

${ }^{17}$ Kertzer, 206.

${ }^{18}$ Kertzer, 97, 216.

${ }^{19}$ Kertzer, 206.

${ }^{20}$ Kertzer, 206.

${ }^{21}$ Kertzer, 203-204.

${ }^{22}$ Kertzer, 216.

${ }^{23}$ Kertzer, 206.

${ }^{24}$ Kertzer, 94, 209-210.

${ }^{25}$ Kertzer, 231.
} 
Did Anna have the right intention? Although she at first said that she did not know what she was doing, ${ }^{26}$ she later stated that she intended to make the child a Christian. ${ }^{27}$ Indeed, according to the Office of the Inquisition, which had interrogated her earlier, Anna stated that she intended to baptize Edgardo according to "the custom of the church." 28

A laywoman could baptize a Jewish child without parental consent in the nineteenth century only under certain conditions: if she determined that the child was in danger of death, if she had no recourse to an available priest or deacon to perform the ceremony, if she used the correct words, if she performed the correct actions, and if she had the right intention. If one believes that the laywoman in question fulfilled all these conditions, then the Jewish boy was baptized a Christian. However, because of divergent testimony, the fulfillment of those conditions is unclear in the case of Edgardo Mortara.

\section{Emergency Baptism Today}

Today, for many reasons, the situation would be different- - though not completely so.

The Catholic Church's baptismal rites for children and for adults were both revised on the authority of the Second Vatican Council. In the revised ceremony for children, the priest or deacon who presides addresses the child infrequently, and never when needing a response. He addresses the parents and godparents instead. The minister never directly addresses the unclean spirit nor inanimate objects such as salt. Exorcisms have been omitted from the ceremonies for children or recast as prayers of protection addressed to God. ${ }^{29}$

The lengthy ceremony of adult baptism now unfolds on distinct occasions into several different stages of initiation. The first of these, the Rite of Acceptance into the Order of Catechumens, opens with the time-honored question, "What do you ask of God's Church?" ${ }^{30}$ The same ceremony then may include an exorcism and renunciation of false worship, wherever such practices are widespread, "whether in worshiping spiritual powers or in calling on the shades of the dead or in using magical arts." ${ }^{31}$ The Catholic bishops of the United States have chosen to leave the use of this renunciation to the discretion of the diocesan bishop. ${ }^{32}$ This is precisely the section where the previous ritual included the renunciation of $\mathrm{Ju}$ daism. That itself has been completely removed.

\footnotetext{
${ }^{26}$ Kertzer, 49.

${ }^{27}$ Kertzer, 208.

${ }^{28}$ Kertzer, 148.

${ }^{29}$ See, for example, "The Rite of Baptism for Children," in The Rites (Collegeville: Liturgical Press, 1990), 49A and B: "Prayer of Exorcism and Anointing before Baptism," 380-381.

30 "The Rite of Christian Initiation of Adults", The Rites, I[48, 55.

31 "Rite of Christian Initiation of Adults," II70, p. 66.

32 "Rite of Christian Initiation of Adults," $\$ 33 \$ 2$, p. 44.
} 
The removal demonstrates the impact of the council's declaration on the relation of the Church to non-Christian religions, Nostra aetate. Its treatment of Jews includes this statement: "Although the Church is the new people of God, the Jews should not be presented as rejected or accursed by God, as if this followed from the Holy Scriptures. All should see to it, then, that in catechetical work or in the preaching of the word of God they do not teach anything that does not conform to the truth of the Gospel and the spirit of Christ." ${ }^{33}$ Following their own advice, the bishops approved a revised liturgical order of adult initiation that provides a spiritual path for Jewish converts to Christianity, without demanding that they ritually repudiate their original religion. Still, the Church retains its belief that baptism constitutes a new covenant, one that fulfills the promises of old. This belief honors the Jewish covenant, while building anew upon its themes and images. ${ }^{34}$

The Church still advises an abbreviated ceremony for a child in danger of death. ${ }^{35}$ Omitting the other rites, the person administering the sacrament "pours water (not necessarily blessed but real and natural water) on the head of the child and pronounces the customary formula." ${ }^{36}$ If no priest or deacon is available, "any member of the faithful, indeed anyone with the right intention, may and sometimes must administer baptism." "Th Thus, the former hierarchy, preferring, for example, men rather than women to administer emergency baptism, has been abolished.

However, the introductory comments still include this note: "If the child is in danger of death, it is to be baptized without delay; this is permitted even when the parents are opposed and even when the infant is the child of non-Catholic parents." 38

Nonetheless, the urgency would not be felt today in the same way as in the past. In the mid-nineteenth century, Catholics believed that the only way to salvation was through baptism. However, the Second Vatican Council considered prospects differently. According to its Dogmatic Constitution on the Church, "Those also can attain to salvation who through no fault of their own do not know the Gospel of Christ or His Church, yet sincerely seek God and moved by grace strive by their deeds to do His will as it is known to them through the dictates of conscience." 39 Or, as the Catechism of the Catholic Church has it, "God has

\footnotetext{
33 "Declaration on the Relation of the Church to Non-Christian Religions," 4. http://www.vatican.va/archive/hist_councils/ii_vatican_council/documents/vatii_decl_19651028_nostra-aetate_en.html.

${ }^{34}$ Turner, "The Amen Corner: Jewish Dialogue and Christian Liturgy." Worship 90 (May 2016): 196204.

35 "Rite of Baptism for Children," 21, p. 372.

36 "Rite of Baptism for Children," 21, p. 372.

37 “Christian Initiation: General Introduction" 16, The Rites, p. 8.

38 "The Rite of Baptism for Children," $8 \S 1$, p. 368.

${ }^{39}$ Dogmatic Constitution on the Church, Lumen Gentium, http://www.vatican.va/archive/hist_councils/ii_vatican_council/documents/vatii_const_19641121_lumen-gentium_en.html, 16.
} 
bound salvation to the sacrament of Baptism, but he himself is not bound by his sacraments. $" 40$

The fear of perdition without baptism spread under the banner that infant baptism cleansed the child from original sin. The Church still teaches this, but not before calling baptism "the door to life and to the kingdom of God" and "the sacrament by which its recipients are incorporated into the Church and are built up together in the Spirit into a house where God lives." ${ }^{41}$ The Church places emphasis more on the corporate fruits of baptism than on its cleansing powers. The Rites of Baptism still mentions original sin in two alternative prayers, both called an "exorcism," though they address God, not an unclean spirit. ${ }^{42}$

Some lay Catholics have performed "emergency baptisms" when there has been no emergency. For example, anecdotally, if Catholic parents delay the baptism of a newborn out of a desire to let the child choose a religion later in life, a Catholic grandparent may decide to baptize the child without informing the parents or acquiring their consent. The baptism, though illicit and ill-advised, is valid. The child has irrevocably become a Christian. The Church still holds that baptism "seals the Christian with the indelible spiritual mark" of belonging to Christ. ${ }^{43}$ Baptism cannot be repeated, nor can it be erased.

\section{A Hypothetical Edgardo}

How, then, would the Church consider the baptism of a post-Vatican II Edgardo Mortara?

The Catholic Church would still permit Anna Morisi to baptize Edgardo under certain conditions. However, the questions that surrounded the preconciliar Edgardo would still haunt the presumptive postconciliar case. Was the child in danger of death? Was no priest or deacon available? Did the adult use the right words? Did she perform the correct actions? Did she have the right intent? Without an affirmative answer to each of those conditions, the validity of the baptism would be questioned.

And what if Anna had been right about Edgardo's condition? What if the infant Edgardo had died? In a pastorally conscious church, aiming to quell the concerns of parents, if an Edgardo today had died after a doubtful emergency baptism, many pastors would give the child the benefit of the doubt - especially if the parents seeking consolation were Christians. However, in the case of Jewish parents, if it seemed more pastorally astute to reassure them that such a baptism was invalid because of a defect, the same action could produce a different pastoral approach in the case of death.

\footnotetext{
${ }^{40}$ Catechism of the Catholic Church 1257, http://www.vatican.va/archive/ccc_css/archive/catechism/p2s2c1a1.htm.

${ }^{41}$ Christian Initiation: General Introduction, Rite of Christian Initiation of Adults, 3-4.

42 "The Rite of Baptism for Children," 49A and B, pp. 380-381.

${ }^{43}$ Catechism 1272.
} 
In addition, if Jewish parents, upon learning of the secret emergency baptism of their child, objected to any attempt to raise the child as a Christian, the Catholic Church today would surely honor their wishes, due to the increased respect for Judaism that has flowed from the reforms of the Second Vatican Council.

Still, the facts remain. If a teenage Catholic girl found herself the only person available at a time when she discerned that the Jewish child in her care was at the very point of dying, even without informing the child's parents or attempting to ascertain their approval, could she baptize? Would such a baptism be valid? The post-Vatican II Rite of Baptism for Children still answers yes. 